\title{
PERFORMANCE OF C SHAPE STRUCTURE WITH INVERTED V SHAPED BRACINGS
}

\author{
Nilesh M. Shinde \\ P.G. Student Civil Dept. \\ Saraswati College of Engineering, Kharghar, India
}

\begin{abstract}
The irregularity in the design of the construction may be due to uneven distribution along the construction height of its mass, strength and stiffness. The assessment and design becomes more complicated when such structures are built in elevated seismic regions. The primary aim of designing an earthquake-resistant structure is to ensure that the building has sufficient ductility to resist the forces of the earthquake. A braced frame is a structural system intended to withstand the forces of wind and earthquake. This research considers the uneven shaped structure of $\mathrm{C}$ and analyzes the actions of distinct types of bracing under lateral load with variability in positions on this uneven framework. It is also considered the impact of lateral load from different directions. V braced frames studied that which bracings are perform under better seismic action comparing with paired structure. Response spectra analyses were performed. Frame structural responses are explored in terms of Time period, storey drift, and displacement of storey shear. The outcome showed a decent increase in lateral frame resistance with bracing.
\end{abstract}

Keywords - Inverted V Bracing, Lateral Loads, Positions of braced

\section{INTRODUCTION}

It has been demonstrated in the previous earthquakes around the globe that construction frames with uneven settings have been significantly damaged compared to periodic ones. There are specific kinds of irregularities (i.e. mass strength and rigidity) in the design of construction frames that can influence their required periodic and predictable reaction to seismic loads significantly different aspects of uneven frame reaction have been recognized by analytical and experimental studies taking into consideration their displacement and ductility requirements in irregularity concentrations.

Distributions of seismic requirements are not the same for frames with distinct irregularities. In addition, uncertainty in seismic demands and the capacity of complex structural systems with different arrangements make it difficult to assess behavior and response of the same structure. therefore, not only should be considered in a seismic design the effects of irregularities in the distributions of stiffness, mass, strength and

\author{
Roshni John \\ Associate Professor Civil Department \\ Saraswati College of Engineering, Kharghar, India
}

their combination, but there are also some geometrically irregular configurations and specific structural features to be investigated.

The lateral force discontinuity owing to building It has been demonstrated in the previous earthquakes around the globe that construction frames with uneven settings have been significantly damaged compared to periodic ones. There are specific kinds of irregularities (i.e. mass strength and rigidity) in the design of construction frames that can influence their required periodic and predictable reaction to seismic loads significantly different aspects of uneven frame reaction have been recognized by analytical and experimental studies taking into consideration their displacement and ductility requirements in irregularity concentrations. Distributions of seismic requirements are not the same for frames with distinct irregularities. In addition, uncertainty in seismic demands and the capacity of complex structural systems with different arrangements make it difficult to assess behavior and response of the same structure. therefore, not only should be considered in a seismic design the effects of irregularities in the distributions of stiffness, mass, strength and their combination, but there are also some geometrically irregular configurations and specific structural features to be investigated.

The lateral force discontinuity owing to building irregularity can be controlled by bracing scheme

\section{CONCEPT OF LATERAL LOAD}

Lateral loads are live loads applied parallel to the surface, which horizontal forces are acting on a structure.

The most common types are:

- $\quad$ Seismic load

- Wind load

- Water and earth pressure.

For small, low level structures, wind load may not be a major problem, but with height it becomes more crucial. During an earthquake, seismic loads may be placed on a structure

\section{STRUCTURE WITH BRACED FRAME}

A braced frame is a structural system that is widely used in laterally charged constructions such as wind and 
seismic pressure. The members in a braced frame are usually produced of structural steel, which can operate in tension and compression efficiently.

- Invert V-Bracing

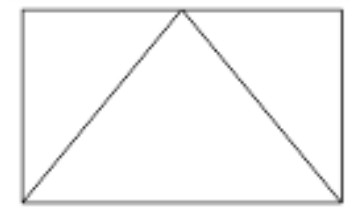

FIG.1 INVERTED V BRACING

\section{DESCRIPTION OF ANALYTICAL MODEL}

The building to be analyzed is a G+19 story building built using IS 456-2000 and 875 (I \& II) 2002 Indian standards. The building plan area is $25 \times 25 \mathrm{~m}$ with a height of $3.5 \mathrm{~m}$ of each typical story (excluding the $2.5 \mathrm{~m}$ height of the bottom story). It's made up of $5 \mathrm{~m}$. X-direction bays and Y-direction bays. The beam and column labels with the sizes of the frame are;

Grade of concrete: M40

Grade of Rebar: Fy415

Grade of Steel: Fe345

Column size: $400 \mathrm{~mm} \times 700 \mathrm{~mm}$

Beam size: $300 \mathrm{~mm}$ x $600 \mathrm{~mm}$

Slab Thickness: $150 \mathrm{~mm}$

Brace section: ISMC 200

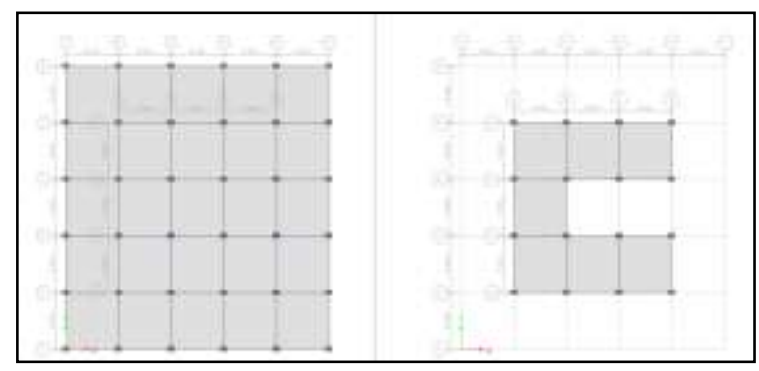

FIG.2 BUILDING PLAN
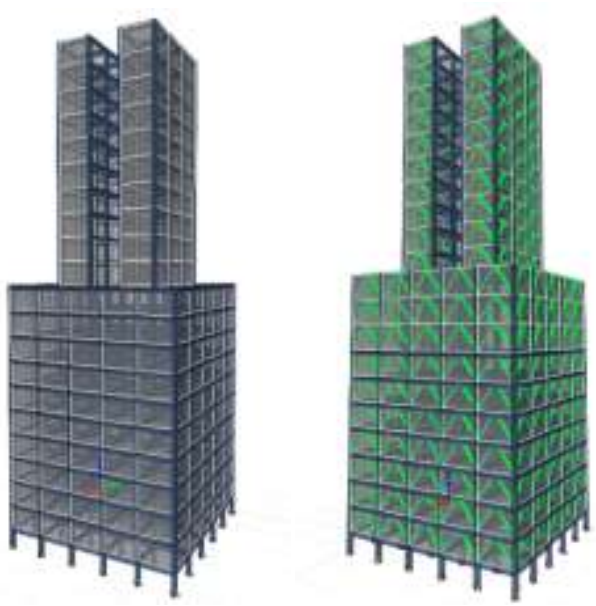

FIG.3 BUILDING MODEL 3D VIEW

A. Positioning of Bracings:

Positioning of bracings can also affect the displacement as well as time Period criteria, different positions of bracings as follows:
a) Fully Braced Frame
b) Adjacent Braced Frame
c) Centrally Braced Frame
d) Adjacent Centrally Braced Frame

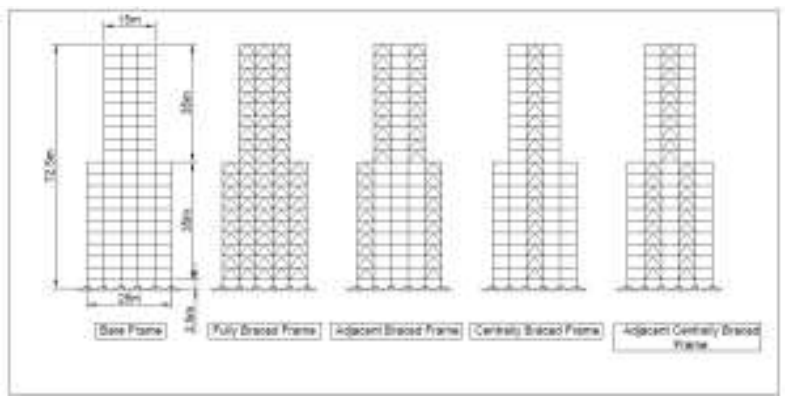

FIG.4 POSITIONS OF BRACED FRAME

B. Modeling of frames:

To investigate the response behavior of the abnormal frames and estimate their seismic parameters, all frames were modeled as a three-dimensional system using the response spectrum analysis program. Important aspect of the method of modeling as follows:

The primary purpose of implementing lateral forceresistant methods to high-rise building is to improve the rigidity when construction is subjected to lateral loads and restrict performance criteria to the specified IS Codes limit. Modeling and analysis is carried out in 3 parts, they are classified as bracing have positioning e.g fully position along with adjacent position. 


\section{RESULT AND DISSCUSSION}

The Result describes Storey Shear, time period, storey displacement and storey drift

TABLE 1.RESULT TABLE

\begin{tabular}{|c|c|c|c|c|}
\hline \multirow{2}{*}{\begin{tabular}{c}
\multirow{2}{*}{$\begin{array}{c}\text { Position } \\
\text { of } \\
\text { Braces }\end{array}$} \\
\cline { 2 - 5 }
\end{tabular}} & \multicolumn{4}{|c|}{ Type of Bracings } \\
\cline { 2 - 5 } & $\begin{array}{c}\text { Storey } \\
\text { Shear } \\
(\mathrm{kN})\end{array}$ & $\begin{array}{c}\text { Timered V- Braced } \\
\text { period } \\
(\mathrm{sec})\end{array}$ & $\begin{array}{c}\text { Sisplacement } \\
(\mathrm{mm})\end{array}$ & $\begin{array}{c}\text { Storey } \\
\text { Drift }\end{array}$ \\
\hline $\begin{array}{c}\text { Bare } \\
\text { frame }\end{array}$ & 1249.137 & 2.66 & 75 & 0.000753 \\
\hline $\begin{array}{c}\text { Fully } \\
\text { Braced }\end{array}$ & 1484.199 & 1.80 & 36.91 & 0.000454 \\
\hline $\begin{array}{c}\text { Adjacent } \\
\text { braced }\end{array}$ & 1351.437 & 2.26 & 52.18 & 0.000522 \\
\hline $\begin{array}{c}\text { Centrally } \\
\text { braced }\end{array}$ & 1301.787 & 2.38 & 60.33 & 0.000626 \\
\hline $\begin{array}{c}\text { Adjacent } \\
\text { centrally } \\
\text { braced }\end{array}$ & 1374.45 & 2.26 & 56.18 & 0.000599 \\
\hline
\end{tabular}

The Response spectrum analysis of model studied in this paper shows following results:

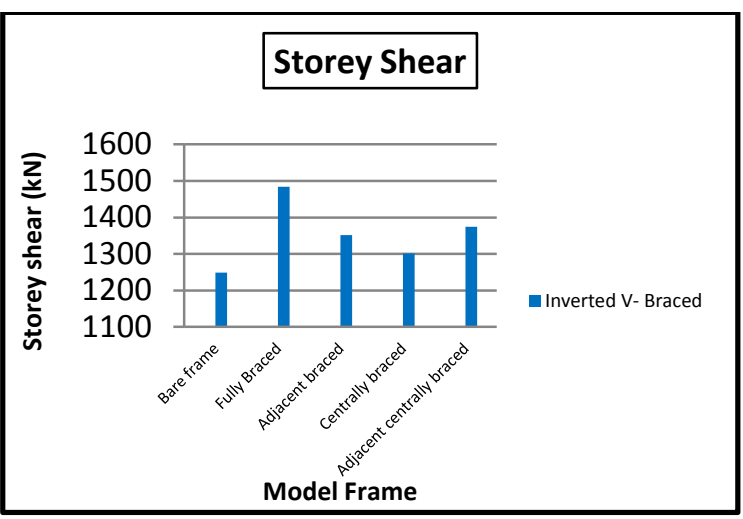

FIG 5. STOREY SHEAR

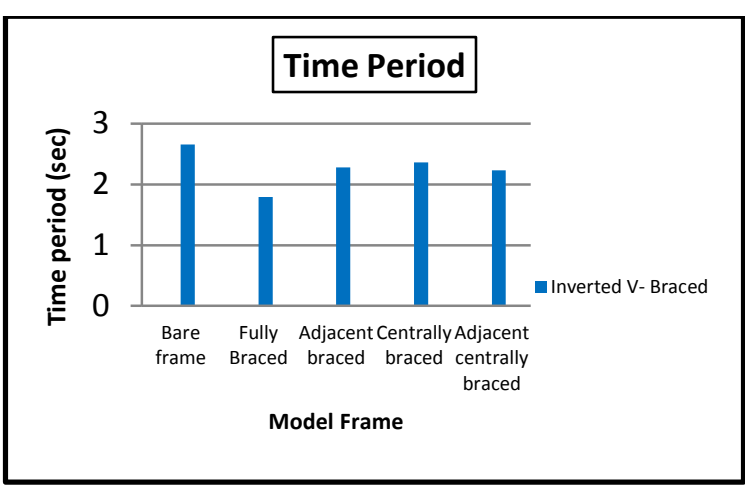

FIG 6. TIME PERIODS

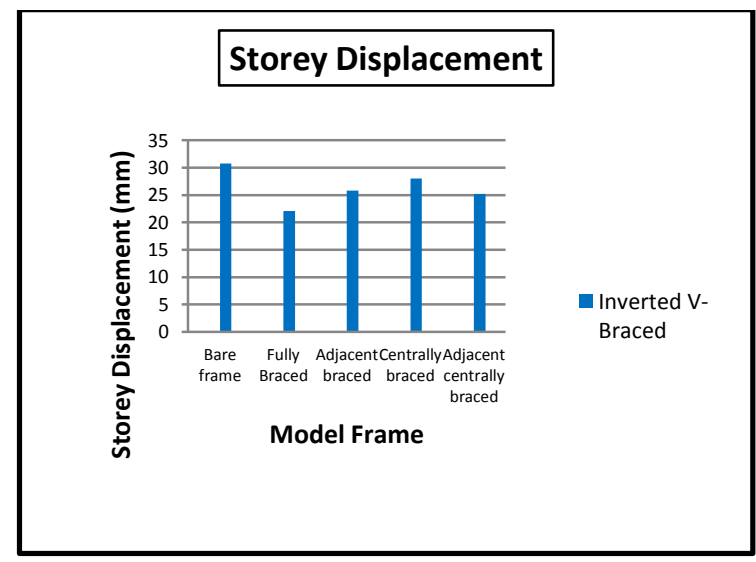

FIG 7.STOREY DISPLACEMNET

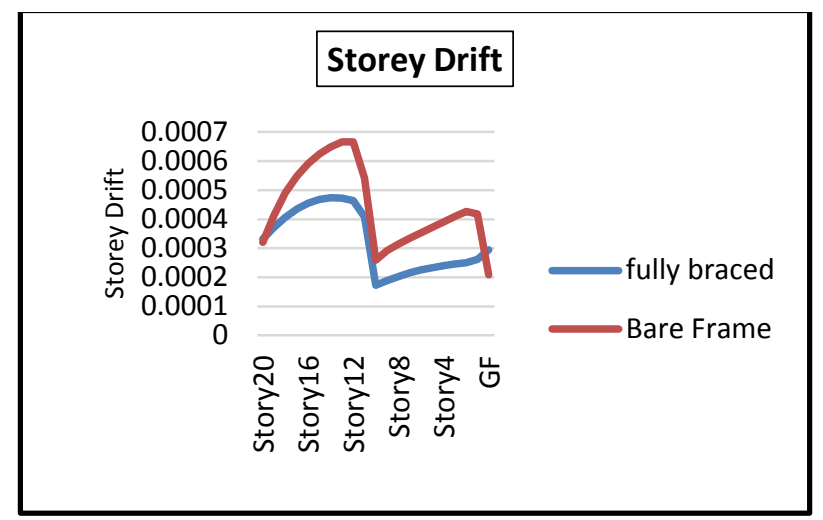

FIG 8.STOREY DISPLACEMNET

The Table values are in the manner of positioning along with bracings, first row show the result of bare system, second row shows result of fully braced system, third column shows adjacent braced system, fourth structure shows centrally braced system and fifth column shows adjacent centrally braced system. 


\section{International Journal of Engineering Applied Sciences and Technology, 2019 \\ Vol. 4, Issue 3, ISSN No. 2455-2143, Pages 173-176 \\ Published Online July 2019 in IJEAST (http://www.ijeast.com)}

\section{CONCLUSION}

After investigating all the models in this paper we conclude that:

1. Time period after bracing the structure is reduce about $15-32 \%$ than that of the bare model.

2. Storey drift after bracing the structure is reducing about $11-37 \%$ than that of the bare model.

3. Storey shear after bracing the structure is Increase about $9-15 \%$ than that of the bare model.

4. Storey displacement after bracing the structure is reducing about $25-48 \%$ than that of the bare model.

5. It is observed that Seismic performance of Inverted $\mathrm{V}$ type bracing is effective

\section{AKNOWLEDGEMENT}

It's a great pleasure and moment of immense satisfaction for me to express my profound gratitude to my guide Prof. Prof. Roshni John, Head of Department whose constant encouragement enabled me to work enthusiastically. Her perpetual motivation, patience and excellent expertise in discussion during progress of the project work have benefited me to an extent, which is beyond expression.

Mr. Kunal Mukane (Structural Engineer) and Mrs. Asawari chavan (Civil Engineer), Raje Consultants Pvt. Ltd. for guidance, but these are the only means at my disposal, I put on the record sentiments of deepest gratitude for them invaluable suggestion and guidance from time to time

\section{CONCLUSION}

1. Nassani.D.E. Hussein A.K.., Abbas J.M.., "Comparative response assessment of steel frames with different bracings system under seismic effect", Elsevier journal, Issue 17, june2017.

2. Rakshit K.L., Smita. "Effect of bracings on multistored RCC frame structure under dynamic loading”, IJARIIT journal, Vol 3, Issue 4, 2017.

3. Moheb khan A. and Marzieh A.., "Seismic behaviour of concentrically braced steel frames with out of plane offset irregularity ", The open civil Engineering journal, Issue 23, June 2016.

4. Sarkar P., Prasad A.M.., Menon D., "Vertical geometric irregularity in stepped building frames", Elsevier Engineering structure, Issue 20, April 2010.

5. Kanyilmaz A., "Role of compression diagonals in concentrically braced frames in moderate seismicity: A full scale experimental study", Elsevier journal of constructional steel research, Issue 27, January 2017.
6. Wood S. L., "Seismic response of R/C frames with irregular profiles", ASCE journal, Issue 5, April 2018.

7. Valmundsson E. V., Nau J. M., "Seismic response of building frames with vertical structural irregularities", ASCE journal, Issue 1, February 2018.

8. Agarwal P., Shrikhande M., "Earthquake resistant design of structure" Ninth edition, August 2011.

9. Taranath B.S.., "Structural analysis and design of tall building", McGraw-Hill, 1988.

10. IS 1893(Part 1):2016 $6^{\text {th }}$ edition criteria for earthquake resistant design of structure; Bureau of Indian standards New Delhi, India. 